Magyar Honvédség Egészségügyi Központ Börgyógyászati Osztály

\title{
Ritka betegség, atípusos börtünetekkel: felnőttkori Still-betegség
}

\author{
Dr. Kása-Kovács Adrienn, \\ Dr. Vajda Adrienne orvos ezredes PhD
}

Kulcsszavak: felnöttkori Still-betegség - atípusos börtünetek - IL-18 - paraneoplázia

\begin{abstract}
A felnőttkori Still-betegség a juvenilis reumatoid artritisz ismeretlen etiológiájú, ritka, felnőttkori variánsa. A szerzők egy 62 éves nőbeteg esetét ismertetik, akit intermittáló magas láz, ízületi fájdalmak, maculo-papulosus bőrtünetek, elesett állapota miatt hoszpitalizáltak. Infekció, reumatológiai betegség, malignus alapbetegség kizárása után, felmerült a felnőttkori Still-betegség lehetősége, melyet az igen magas, izoláltan emelkedett ferritin szint is alátámasztott. A szerzők a cikkben öszszefoglalják ezzel a komoly diagnosztikus kihívást jelentő betegséggel kapcsolatos új ismereteket is.
\end{abstract}

A felnőttkori Still-betegség ismeretlen eredetü, szisztémás gyulladásos betegség, amelyet intermittáló lázmenet, a lázzal egyidőben jelentkező lazacvörös maculo-papulosus exantéma, artritisz, szerozitisz, splenomegália, neutrofil leukocitózis, limfadenomegália jellemez. A tüneteket gyakran torokfájdalom vezeti be. A nemek közötti megoszlásban nem mutatkozik különbség. A betegek 70\%-ában emelkedett a szérum ferritin szint. Diagnózisa a mai napig elsősorban kizárásos diagnózis, illetve Yamaguchi 1992-ben felállított kritérium rendszere alapján történik, amely 4 major és 5 minor kritériumot említ. A diagnózis felállításához 5 kritériumnak kell teljesülnie, amelyek közül 2 major kritérium. Kezelésében NSAID, kortikoszteroid, methotrexat, intravénás immunglobulin, biológiai szerek (IL-1 receptor antagonista Anakinra, Canakinumab, IL-6 antagonista Tocilizumab és TNF- $\alpha$ inhibitor) állnak rendelkezésünkre.

\section{Esetismertetés}

A 62 éves nőbeteg anamnézisében tonsillectomia, nefrolitiázis, mióma miatt, hysterectomia, discus hernia, isiász miatti kezelés szerepelt. 2012 nyarán a bal emlőből intraduktális karcinómát távolítottak el, axilláris blokk disszekcióval, majd kemoterápiás és radioterápiás utókezelése is történt. A mütét óta Letrozolt szedett. A bal felkar limfoödémája miatt rendszeresen járt nyiroködéma mentesítő kezelésekre. Utolsó onkológiai kont- 
rollja 2016 decemberében volt, mammográfia, mellkas röntgen, hasi ultrahang vizsgálatai történtek, amelyek az alapbetegség progresszióját nem igazolták.

Panaszai felvétele előtt $\mathrm{kb}$. három héttel kezdődtek, torokfájással, hőemelkedéssel, majd $39{ }^{\circ} \mathrm{C}$-os lázzal, amely jellegzetesen az esti órákban jelentkezett. Ezt követően orcáin élénk eritéma, testszerte élénk-eritémás, maculopapulosus exantémák, a lábszárakon purpuriform papulák, tenyerein nagy elemű hámlás alakult ki. Bőrtüneteit, lázát kifejezett nagyízületi fájdalmak kísérték, amelyek mozgáskorlátozottságot okoztak. Üzemorvos orális azitromycint kezdett, amely mellett általános állapota tovább romlott. Ismeretlen eredetü láza miatt családorvosa belgyógyászati kivizsgálást indított. Hasi ultrahang kolelitiázist igazolt gyulladásos jelek nélkül. A láz hátterében a kardiológus az endokarditiszt kizárta. Mellkas röntgen aktuális kórosat a tüdőkben nem írt le. Labor értékeiből jelentősen emelkedett CRP (164,8 mg/l), neutrofilia, gyorsult süllyedés $(55 \mathrm{~mm} / \mathrm{h})$ emelendő ki. Láza miatt a Szent László Kórház láz szakrendelésén járt, az itt készült laborban csökkent C3, C4 komplement szint, kifejezett LDH emelkedés, negatív dsDNA AT, ENA panel, RF értékek voltak.
Parvovirus B19 IgG pozitiv lett, IgM nem. Procalcitonin (PCT) értéke nem volt emelkedett.

Felvételekor a háton és a mellkason látott élénk-eritémás maculo-papulosus exantémái lineáris elrendeződést mutattak (1-4. ábra). Combokon, felkarokon urticariform élénk-eritémás papulákat láttunk. Lábszáron látható purpuriform bőrtünetei, ellentétben a mellkas stabil tüneteivel, napról napra változtak, majd teljesen megszűntek maradványtünetek hátrahagyása nélkül. Bőrtünetei mérsékelten viszkettek. A beteg a lázas időszakok alatt kifejezetten elesett volt, míg láztalan állapotban kevés panaszt említett. Osztályunkon vett laborból GOT (70 U/l), GPT (37 U/l), GGT (44 U/l), LDH (1118 U/l), ALP (368 U/l), CRP $(119,85 \mathrm{mg} / \mathrm{l})$ emelkedés, vizelet üledékben 1+ leukocita, 3+ eritrocita, $2+$ bilirubin emelendő ki. Belgyógyászati konzílium után alapbetegségének propagációja, szekunder neoplazma, illetve kolecisztitisz lehetősége merült fel. Hasi ultrahang vizsgálata kolelitiázist írt le, gyulladásos jelek nélkül, a lép nagysága a normális méret felső határán volt. Gasztroenterológiai és sebészeti konzílium alapján a kolecisztitiszt kizártuk. Torokfájdalma miatt fül-orr-gégészeti konzílium történt negatív eredménnyel.

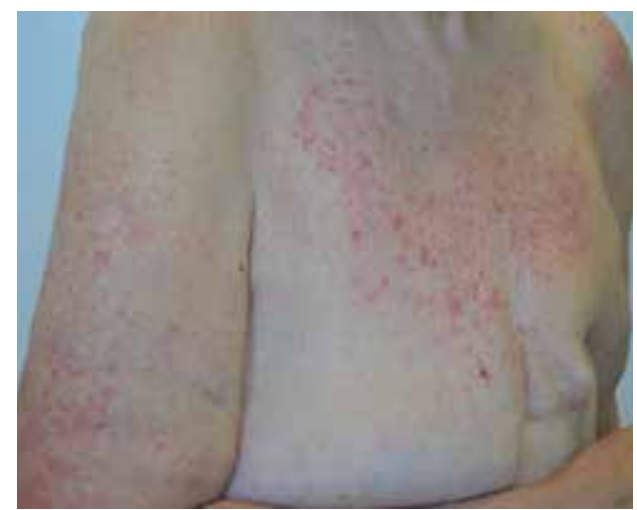

1. ábra

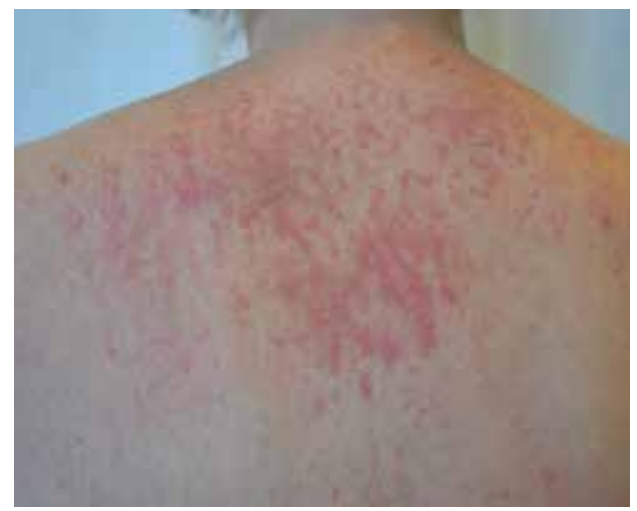

2. ábra 


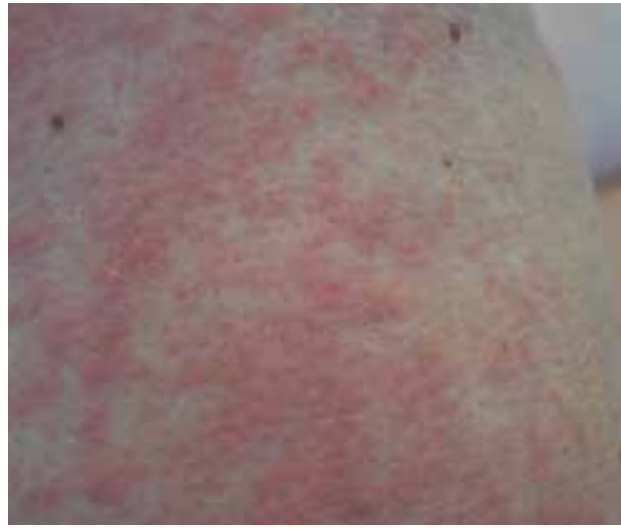

3. ábra

AST nem volt emelkedett. Torokváladék tenyésztése negatív volt. Lázas állapotok alatt vett hemokultúrákból egy alkalommal koaguláz negatív Staphylococcus aureus tenyészett ki, amelyet kontaminációnak tartottunk, a többi hemokultura negatív maradt. PCT nem emelkedett meg. Szérum elektroforézisben alfa 1-globulin és alfa 2-globulin frakció emelkedett volt, albumin értéke csökkent, monoklonális gammopátia nem volt kimutatható. Retikulocita száma alacsony volt $(2,9 \%)$. Posztinfekciós szerológia, hepatitisz szerológiái, szifilisz szürése szintén negatív lett. Onkológiai konzílium panaszai hátterében felvetette Letrozol mellékhatást, illetve paraneoplázia lehetőségét, amely miatt CEA, CA15-3, CA125, CA19-9 tumormarker vizsgálatokat végeztünk, negatív eredménnyel. A beteg a Letrozolt 3 éve szedte panasz nélkül.

A klinikai kép, a gyorsan változó bőrtünetek és a jellegzetes lázmenet miatt felmerült a Still-betegség lehetősége, ezért reumatológiai konzíliumot kértünk, mely panaszai hátterében a hemokulturából kitenyészett Staphylococcust véleményezte kiváltó okként, ezt azonban nem tartottuk megalapozottnak, ezért szérum ferritin,

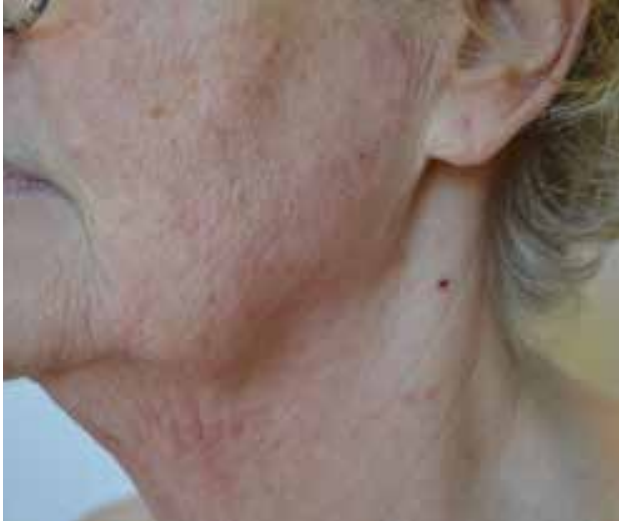

4. ábra

transzferrin, és szérum vas szintjeit ellenőriztük. Ferritin értéke extrém magas volt $(30489 \mathrm{ng} / \mathrm{ml})$, míg a többi labor értéke nem volt kóros. Magas dózisú orális szteroidot kezdtünk, amely mellett artralgiája megszűnt, láztalanná vált, bőrtünetei regrediáltak, általános állapota rapidan javult. Kétnapi szteroid adás után készült laborban LDH (442 U/l), CRP (41,33 mg/l), ferritin (3859 $\mathrm{ng} / \mathrm{ml}$ ) értékei jelentősen csökkentek. Javult állapotban a beteget emittáltuk.

Ambuláns utánkövetése során alacsony dózisú szteroid mellett tartós remisszióban maradt, kontroll laborokban, vizelet üledékben eltérés nem volt. Jelenleg a szteroid elhagyása mellett a beteg tünet- és panaszmentes.

\section{Megbeszélés}

A felnőttkori Still-betegség ismeretlen eredetü, ritka gyulladásos betegség. Prevalenciája retrospektív tanulmányok szerint 0,16/100000/év Franciaországban, 0,4/100000/év Norvégiában, Japánban valamivel magasabb 0,22/100000/év. $(2,4,19,23,24) 1897$-ben Sir George Frederick Still jelentette az első olyan gyermekkori eseteket, amelyekben a reumatoid artritisz szisztémás tünetekkel járt. Né- 
hány évvel később kerültek látótérbe az idősebb korban jelentkező esetek, amelyeket ekkor még Wissler-Fanconiszindrómaként írt le az irodalom, majd 1971-ben E.G. Bywaters használta elöször a felnőttkori Still-betegség megnevezést. $(1,19)$ Definíció szerint 16 éves kor felett már felnőttkori Still-betegségről beszélhetünk, ugyanakkor meg kell említeni, hogy az enyhébb lefolyású juvenilis formák néha nem kerülnek diagnosztizálásra, illetve a betegség kezelés nélkül is remisszióba kerülhet, majd évek múlva, immár „felnőtt korban” relapszálódik [2].

A nemek közötti megoszlásban nem mutatkozik különbség. Kor szerint két előfordulási csúcsot ír az irodalom, 15 és 25 év között, valamint 35 és 45 év között $[1,4]$. Lefolyása során egyetlen akut shub, esetleg évek múlva relapszálódó és krónikus forma is ismert. Ez utóbbi esetben két altípust figyeltek meg. Míg egyik formában inkább a láz, szisztémás tünetek dominálnak, addig a másik formában az ízületi érintettség kifejezettebb, ezekben az esetekben a betegség az ízületi porcot és a csontfelszínt is érinti, destruálja [1,2].

Etiológiája máig ismeretlen. Vírusok (rubeola, echovírus 7, mumps, kanyaró, Epstein-Barr vírus, citomagelovírus, parainfluenza vírus, Parvovírus B-19, coxackie, HHV6, hepatitis B és $C$ vírus, influenza A vírus, adenovírus), bakteriális ágensek (Yersinia enterocolica, Mycoplasma pneumoniae, Chlamydia pneumoniae, Brucella abortus, Borrelia burgdorferi), illetve genetikai faktorok (HLA DRB1*1201 és 1501, BR25, DR2, DR5) is szerepet játszhatnak a betegség kialakulásában $[4,19]$.

$\mathrm{Az}$ utóbbi években megjelent számos cikk utal az atípusos tünetekkel jelentkező betegség esetén annak paraneopláziás jellegére. Az esetek döntő többségében solid tumor (emlö, illetve tüdő karci- nóma), vagy hematológiai tumor (elsősorban limfóma) jelentkezett, ezért a betegek hosszútávú követését javasolják [12,22].

Patomechanizmusában elsődleges szerepet tulajdonítanak az IL-18-nak, amely a betegség akut shubja alatt kimutathatóan emelkedik. Az IL-18 szerepet játszik az INF- $\gamma$, és a TNF- $\alpha$ termelésben, és a Th1 és Th17 sejtek aktivációjában. Feltételezik, hogy az IL-18-nak szerepe van a ferritin szintézisében is [3].

A diagnózis felállításában leginkább elfogadott kritériumrendszert 1992-ben állította fel Yamaguchi, amelyet azóta is a legelterjedtebben használnak. Ennek megújítására tettek kísérletet 2002-ben Fautrel és mtsai (1. táblázat) A legszenzitívebbnek $(96,2 \%)$ és megbízhatóan specifikusnak $(92,1 \%)$ tartott Yamaguchiféle kritériumok hátránya a nagyszámú egyéb betegség, melyet ki kell zárni, míg a kevésbé szenzitív (80,6\%), de sokkal specifikusabb (98,5\%) Fautrel kritériumok hátránya a glikozilált ferritin szint mérése, amelyet nem tudunk rutinszerüen mindenhol elvégezni $[4,5,24]$.

A betegek magas $\left(\geq 39^{\circ} \mathrm{C}\right)$ lázról számolnak be, amely jellegzetesen intermittálóan jelentkezik, egy vagy kétnapi csúccsal. Erősödő ízületi fájdalom esetleg izomfájdalmak jellemzik, melyek kezdetben általában egy ízületre lokalizáltak. Elsősorban a nagyízületek, főleg a térd, könyök, boka és csukló érintettek, ritkábban a vállak és a kéz kisízületei [4]. A lázzal egyidőben jelentkező típusos maculo-papulosus, lazacvörös rash elsösorban a törzsön és a végtagokon figyelhető meg, néha a tenyereket és a talpakat is érinti.

A típusos rash annyira jellegzetes, hogy a major kritériumok között szerepel, azonban az utóbbi években számos közleményben atípusos bőrtünetek is 


\section{I. táblázat}

\begin{tabular}{|c|c|}
\hline Yamaguchi és mtsai. 1992 & Fautrel és mtsai. 2002 \\
\hline Major kritériumok & Major kritériumok \\
\hline $\begin{array}{l}\text { láz:> } 39^{\circ} \mathrm{C} \text {, legalább egy hete tartó, } \\
\text { intermittáló lázmenettel }\end{array}$ & láz:> $39^{\circ} \mathrm{C}$, intermittáló lázmenet \\
\hline több, mint két hete tartó arthralgia & arthralgia \\
\hline típusos rash & átmeneti erythema \\
\hline \multirow[t]{3}{*}{ 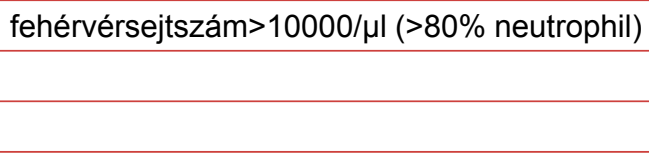 } & polymorphonuclearis sejtek száma $>80 \%$ \\
\hline & pharyngitis \\
\hline & glycosilált ferritin $\leq 20 \%$ \\
\hline Minor kritériumok & Minor kritériumok \\
\hline torokfájdalom & maculo-papulosus rash \\
\hline $\begin{array}{l}\text { lymphadenopathia és/vagy splenomegalia } \\
\text { és/vagy hepatomegalia }\end{array}$ & 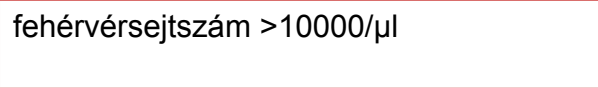 \\
\hline \multicolumn{2}{|l|}{ negatív ANA, RF } \\
\hline \multicolumn{2}{|l|}{ emelkedett májfunkciós értékek } \\
\hline \multicolumn{2}{|l|}{ Kizárásos kritériumok } \\
\hline \multicolumn{2}{|l|}{$\begin{array}{l}\text { fertőzések, malignus alapbetegség, } \\
\text { reumatológiai betegség }\end{array}$} \\
\hline $\begin{array}{l}\text { diagnózis felállitása } 5 \text { kritérium megléte } \\
\text { esetén, melyből } 2 \text { major kritérium }\end{array}$ & $\begin{array}{l}\text { diagnózis felállítása } 4 \text { major, vagy } 3 \text { major } \\
\text { és } 2 \text { minor kritérium esetén }\end{array}$ \\
\hline
\end{tabular}

leírásra kerültek. Ilyenek az esetünkben is megfigyelt stabil, kissé urticariform, felszínén esetenként diszkréten hámló, élénk eritémás, maculo-papulosus exanthema, amely elsősorban a mellkas és a hát felső részén, a végtagok disztális részén jelenik meg, gyakran lineáris jelleggel $[6,7,11,13,18]$. Jelentkezhetnek vezikulózus, akár pusztulózus, akneiform, a lábszárakon purpuriform tünetek, urticaria is, a szemhéjak ödémája dermatomiozitiszt utánozhat $[9$, $11,13]$.

A típusos börtünetek szövettana nem specifikus, enyhe perivaszkuláris histiocitás, limfocitás beszürődést látunk a dermisz felső rétegében, direkt immunfluoreszcencia immunglobulin és komplement irányában általában negatív $[3,4]$. A nem típusos, stabil tünetekböl vett szövettani mintákban parakeratózis, akantózis, perivaszkulárisan limfocitás és eozinofil sejtes beszürődés alakul ki vaszkulitisz nélkül, a dermisz felső rétegében neutrofil és eozinofil sejtes beszürődés figyelhető meg, általában mucin felszaporodás nélkül $[5,6]$. Együttes előfordulása leukocytoclastikus vaszkulitisszel extrém ritka [1].

A láz, artritisz, bőrtünetek mellett nem szuppuráló faringitisz, limfadenomegália, splenomegália, hepatomegália is jelentkezik, a májfunkciós értékek eleváltak. Ritkábban a perikardium és a pleura érintettségével járó szerozitisz, tüdőinfiltrátumok is kialakulhatnak.

Szövődményeként jelentkezhet reaktív hemofagocitás-szindróma, amely a citotoxikus T-limfociták és a természetes ölősejtek kontrollálatlan aktiválódása és funkcionális zavara, illetve a következményes generalizált makrofág 
aktiváció miatt kialakuló extrém gyulladással társuló, potenciálisan életet veszélyeztető immunszabályozási zavar, akut légzési elégtelenség, miokarditisz, perikardiális tamponád, fulmináns hepatitisz, sokk, trombotikus mikroangiopátiák, AA amyloidosis $[4,19,21]$.

A laboratóriumi paraméterek értékelése során, neutrofil leukocitózist, anémiát, trombocitózist, gyorsult süllyedést, emelkedett szérum CRP szintet, a már említett emelkedett májfunkciós értékeket, negatív autoimmun panelt és reuma faktort, negatív vírus szerológiai teszteket, hemokulturát, negatív torokváladék tenyésztést láthatunk. [2, 4, 17]. Sok esetben eltérés jelentkezik az alvadási paraméterekben, akár disszeminált intravaszkuláris koaguláció is kialakulhat [4].

A szérum ferritin szintje jelentősen emelkedik (>3000 ng/ml), míg a szérum Fe, szérum transzferrin és a transzferrin szaturáció értékek nem változnak ezzel párhuzamosan $[1,5]$. A ferritin egy olyan szérum protein, amelynek szintje a szervezetben zajló gyulladásos folyamatok során emelkedik. A felnőttkori Stillbetegség akut fázisa alatt a szérum ferritin szintje extrém magasra, néha 50000 ng/l fölé emelkedik. A szérum érték ötszörös emelkedése $41 \%$-os specificitással, és $80 \%$-os szenzitivitással jelzi a betegséget. Ezzel egyidőben a szérum ferritin egy izotípusának a glikozilált ferritinnek (GF) a szintje csökken. Egészséges egyénekben a GF a szérum ferritin 50-80\%-t teszi ki, míg a betegség akut szaka alatt 20\%-ra csökken, és a remissziók alatt a szérum ferritin szinttel ellentétben nem normalizálódik $[10,15,16]$. E két érték együttes vizsgálata tovább növeli a diagnosztika szenzitivitását $[4,5]$.

Számos tanulmány próbált a diagnózis felállításában segítséget jelentő egyéb biomarkereket meghatározni.
A szérum IL-18, prokalcitonin, S-100, szérum CD163 markerek szerepe és a diagnosztikus haszna még további vizsgálatokat igényel $[15,16]$.

Radiológiai eltérések krónikus, ízületet érintő formákban, hosszabb betegség fennállás után a betegek $\mathrm{kb}$. 40\%-ában alakulnak ki. Ezek főleg a karpo-metakarpális, ritkábban a tarzometatarzális ízületet érintik. A legsúlyosabb ízületi destrukció általában a térdízületben alakul ki $[4,19]$.

Differenciál-diagnosztikai szempontból infekciókat, malignus tumorokat, egyéb autoimmun betegségeket kell elsősorban kizárnunk, köztük a hasonló lázmenettel, rekurráló urticariform bőrtünetekkel, ízületi érintettséggel járó, de mindig monoklonális IgM gammopátiához kapcsolódó Schnitzlerszindrómát, illetve a hasonló labor eltérésekkel, nyaki limfadenopátiával, lázzal, hepatomegáliával járó, és a felnőttkori Still-betegséggel néhány esetben együtt jelentkező Kikuchi-betegséget (nekrotizáló hisztiocitás limfadenitisz) $[3,8,20]$.

A kezelésében alkalmazott terápia részben empirikus, részben kis esetszámú retrospektív vizsgálatokon alapul, kettős vak randomizált vizsgálatok nem állnak rendelkezésünkre, azonban az utóbbi időkben alkalmazott biológiai terápiák jó effektivitásáról számolnak be. A kezelésben korábban alkalmazott nonszteroid gyulladásgátlók (NSAID), csak a kezdeti szakban javasoltak, főleg tüneti szerként, a betegség lefolyását nem változtatják meg, és a szövődmények megakadályozására nem alkalmasak, ha mégis adásra kerülnek elsősorban magas dózisú (150-250mg/nap) indometacin alkalmazása javasolt. (19) A kezelésben hatásosnak találták a kortikoszteroidokat és megfigyelték, hogy nagyobb dózi- 
sok alkalmazása mellett $(0,5-1 \mathrm{mg} / \mathrm{ttkg})$ gyorsabb és tartósabb remissziót értek el, mint alacsonyabb dózisok alkalmazása mellett. A hatás már néhány órán, napon belül jelentkezett. A betegeknek azonban kb. 42-45\%-ában alakul ki szteroid dependencia, amely föleg a fiatalabb életkorban jelentkező, jelentősen gyorsult süllyedéssel, szplenomegáliával járó esetekre jellemző. A hosszútávú szteroid kezelés mellékhatásainak mérséklésére, és főleg krónikus, ízületi érintettséggel járó formákban methotrexat (7,5-17,5mg/hét) kerülhet bevezetésre, amely a szteroid dependens betegek 40-70\%-ában volt hatásos. Az emelkedett májfunkciós értékek nem jelentenek abszolút kontraindikációt a használatában, ilyenkor szorosabb ellenőrzés javasolt. A cyclosporine-A-t (2,5-5 mg/ nap) szintén hatásosnak találták a betegség kezelésében, azonban a betegek roszszabbul tolerálták, mint a methotrexatot. Intravénás immunglobulin (IVIG) adására tett kísérletek is történtek, ezek azonban nem voltak effektívebbek a korábban leírt terápiáknál, ugyanakkor kevés mellékhatással jártak, és havi egyszeri infúzió hatásosan kontrollálta a betegséget terhesek esetében, illetve alkalmazása kifejezetten javasolt reaktív hemofagocitás-szindróma esetén [24]. A biológiai terápiák közül a TNF- $\alpha$ gátló szerek elsősorban a más terápiákra nem reagáló, főleg ízületi érintettséggel járó krónikus esetekben bizonyultak hatásosnak, bár alkalmazásuk során reaktív hemofagocitás-szindróma fordult elő adalimumab és etanercept kezelés mellett. Hosszútávon a betegek felében hatásvesztés alakult ki. Tartós remissziót csak a betegek 25\%-ában lehetett elérni. Az IL-1 $\beta$ receptor antagonista hatású, Anakinra viszont jól tolerálható, gyors javulást adó terápiás lehetőség, a betegek $50-80 \%$-ában tartós remissziót ér el, habár elhagyása után relapszus elöfordult. A napi adagolási séma és a helyi reakciók elöfordulása miatt a hosszabb felezési idejű, ezért ritkábban adandó Canakinumabot alkalmaztak fiatalabb betegek esetében, szintén jó hatásfokkal. Az IL-6 antagonista tocilizumab az előbbiekhez hasonlóan csökkentette mind az ízületi, mind a szisztémás panaszokat, adása során kevés mellékhatást tapasztaltak $[2,4,14,17,19]$.

Cikkünkkel szeretnék felhívni a figyelmet erre a ritka, és sok kihívást tartogató betegségre, melynek diagnosztizálásában kiemelt szerepet kapnak a bőrtünetek, így azok ismerete segít a mielőbbi diagnózis felállításában.

\section{Irodalom}

[1] Champa Nataraja, Griffiths H.: Atypical cutaneous manifestations in adult onset Still's diseae. Case Reports in Rheumatology, 2016, ID 4835147, 4.

DOI: $10.1155 / 2016 / 4835147$

[2] Fautrel, B.: Adult-onset Still's disease Orphanet encyclopedia, 2004. http://www. orpha.net/data/patho/GB/uk-still.pdf

[3] Toshiyuki Yamamoto: Cutaneous manifestations associated with adult-onset Still's disease: important diagnostic values. Rheumatol. int., 2012, 32: 2233-2237.

DOI: $10.1007 / \mathrm{s} 00296-011-2330-\mathrm{z}$

[4] Naim Mahroum, Hussein M., Howard, A.: Diagnosis and classification of adult Still's disease. Journal of Autoimmunity, 2014, 4849: 34-37.

[5] Fautrel, B., Zing, E., Golmard, J. L. et al.: Proposal for a new set of criteria for adultonset Still' disease. Medicine (Baltimore), 2002, 81: 194-200.

[6] Eri Hotta, Noriaki Nakai, Norito Katoh: Persistent pruritic eruptions in adult-onset Still's disease: additional histopathological findings. Acta Dermatovenerol. Croat., 2015; 23 (2): 146-147. 
[7] Yoshifuku, K. Kawai, Kanekura, T. : Adultonset Still disease with peculiar persistent plaques and papules. Clinical and Experimental Dermatology, 2014, 39: 503-505.

DOI: $10.1111 /$ ced. 12335

[8] Karen A. Toribio, Hideko Kamino, Stephanie $\mathrm{Hu}$ et al.: Co-accurance of KikuchiFujimoto's disease and Still's disease: Case report and review of previously reported cases. Clin. Rheumatol., 2015, 34: 2147-2153. DOI: 10.1007/s10067-014-2755-3.

[9] Narváéz Garcia , F., J., Pascual, M., Mercé López de Recalde et al.: Adult-onset Still's disease with atypical cutaneous manifestations. Medicine, 2017, 96:11 (e6318).

DOI: 10.1097/MD.0000000000006318.

[10] Gerfaud-Valentin, M., Maucort-Boulch, D., Hot, A. et al.: Adult-onset Still disease. manifestations, treatment, outcome and prognostic factors in 57 patients. Medicine, 2014, 93 (2): 91-98.

DOI: 10.1097/MD.0000000000000021.

[11] Nobuyuki Kikuchi, Matassa Satoh, Mikio Ohtsuka M. et al.: Persistent pruritic papules and plaques assosiated with adult-onset Still's disease: Report of six cases. Jap. J. Derm., 2014, 41: 407-410.

[12] Sun, N. Z., Berzinski, E., A., Berliner, J. et al.: Updates in adult-onset Still disease: atypical cutaneous manifestations and assosiations with delayed malignancy. J. Am. Acad. Dermatol., 2015, 73: 294-303.

DOI: $10.1016 /$ j.jaad.2015.04.063

[13] Zeynep Meltem Akkurt, Mehtap Bozkurt, Drrya Ucmak et al.: Atypical cutaneous features in adult onset Still's disease. Indian J. Dermatol., Venereol Leprol., 2014, 80: 250-253.

DOI: $10.4103 / 0378-6323.132254$

[14] Dae Hyun Yoo: Treatment of adult onset Dtill's disease: up to date. Expert Rev. Clin. Immunol., 2017, 13 (9): 849-866.

DOI: 10.1080/1744666X.2017.1332994

[15] Mitrovic, S., Fautrel, B.: New markers for adult-onset Still's disease. Joint Bone Spine, 2017 May 18.

DOI: 10.1016/j.jbspin.2017.05.011
[16] Colafrancesco, S., Priori, R., Valesini, G. et al.: Presentation and diagnosis of adult-onset Still's disease: the implication of current and emerging marker sin overcoming the diagnostic challenge. Expert Rev. Clin. Immunol., 2045, 11: 749-761.

DOI: $10.1586 / 1744666$ X.2015.1037287

[17] Sfriso, P., Priori, R., Valesini, G. et al.: Adultonset Still's disease: an Italian multicentre retrospective observational study of manifestations and treatment in 245 patients. Clin. Rheumatol., 2016, 35: 1683-1689.

DOI: $10.1007 /$ s10067-016-3308-8

[18] Jianjun Qiao, Juan Bai, Hong Fang: Persistent pruritic lesions in adult onset Still' disease. Am. J. Med. Sci.: 2016; 352 (5): 540-541.

DOI: 10.1016/j.amjms.2016.03.016

[19] Gerfaud-Valentin, M., Jamilloux, Y., Iwaz, J. et al.: Adult-onset Still's disease. Autoimmun Rev. 2014, 13: 708-722.

DOI: 10.1016/j.autrev.2014.01.058.

[20] Cozzi, A,, Papagrigoraki, A., Biasi, D. et al.: Cutaneous manifestations of adult-onset Still's disease: a case report and review of literature. Clin. Rheumatol., 2016, 35: 1377-1382.

DOI: $10.1007 / \mathrm{s} 10067-014-2614-2$.

[21] Yun Zhang, Yingyun Yang, Yujia Bai et al.: Clinical characteristics and follow-up analysis of adult-onset Still's disease complicated by haemophagocytic lymphohistiocytosis. Clin. Rheumatol., 2017, 35: 1145-1151.

DOI: $10.1007 / \mathrm{s} 10067-016-3178-0$

[22] Yamaguchi M., Ohta A., Tsunematsu T. et al.: Preliminary criteria for classification of adult Still's disease. J. Rheumatol., 1992, 19: 424431.

[23] Magadur-Joly, G., Billaud, E., Barrier, J. H. et al:: Epidemology of adult Still's disease: estimate of the incidence by a retrospective study in west France. Ann. Rheum. Dis., 1995, 54(7): 587-590.

[24] Wakai K., Ohta A., Tamakoshi A. et al.: Estimated prevalence and incidence of adult Still's disease: findings by a nationwide epidemological survey in Japan. J. Epidemiol., 1997, 7: 221-225. 
Adrienn Kása-Kovács MD,

Col. Adrienne Vajda MDMC, PhD

\section{Adult Onset Still's disease with atypical cutaneous manifestations}

The adult onset Still's disease is a rare variant of the systemic juvenile rheumatoid arthritis of unknown origin. This case report is about a 62-year-old woman, who was hospitalized with high recurrent fever, arthralgia and maculopapular rash, in very bad condition. After excluding any infectious, rheumatologic and malignant disease, the possibility of Still's disease had been confirmed by extreme elevated serum ferritin level. This case report reviews current knowledge about this disease, pointing out it's diagnostic challenge.

Keywords: Adult Onset Still's

disease-atypical cutaneous

manifestations - IL-18-paraneoplasia

Dr. Kása-Kovács Adrienn

1062 Bp., Podmaniczky u. 109-111. 